\title{
THE KUUSAMO DRUMLIN FIELD, NORTHERN FINLAND
}

\author{
GunNar Glückert
}

\begin{abstract}
GlüCKert, Gunnar 1974: The Kuusamo drumlin field, northern Finland Bull. Geol. Soc. Finland 46, 37-42.
\end{abstract}

\begin{abstract}
There are a large number of drumlins in Kuusamo, north Finland, where they form a large field with about 2400 ridges of various shapes and sizes. Glacial geological investigation of the Kuusamo drumlin field is described in this paper. The elongated ridges can be divided into high, irregular vaara drumlins and typical drumlins, with three subtypes of low bog drumlins, higher ridges and narrow esker-like drumlins. The area of Kuusamo was drumlinized under the continental ice advancing from the WNW-NW.
\end{abstract}

Gunnar Glïckert, Institute of Quaternary Geology, University of Turku, SF-20500 Turku 50, Finland.

\section{Introduction}

The ancient glaciated terrain of Finland seems to have been more or less drumlinized under the ice. Coherent drumlin fields were formed in different parts of Finland, e.g. in the southern and eastern parts of the country(Frosterus 1912, Hänninen 1915, Sauramo 1928, Tanner 1938, Virkkala 1949, 1961, Aartolahti 1966 and Glückert 1973). The Kuusamo drumlin field lies about $200 \mathrm{~km} \mathrm{NE}$ from the town Oulu on the FinnishRussian border in the SE part of northern Finland. The field covers about 3700 sq. $\mathrm{km}$ and contains about 2400 drumlins of various sizes and types. The Kuusamo drumlin field continues over the border in the U.S.S.R. The drumlins of Kuusamo were mentioned in the papers published by Hänninen (1915) and Tanner (1938). No detailed investigation of these drumlins has been made before (Fig. 1).

The purpose of this paper is to describe the results of glacial geological field investigations made in Kuusamo in July 1973 in connection with 36 topographical map sheets scale 1 : 20000 . The most important thing was to map all the drumlins in the area, divide them into various types and explain their genesis on the basis of shape, material and orinetation of the ridges in the field. The results show that the drumlins in Kuusamo vary from those investigated by the author in central Finland (Glückert 1973). The whole drumlin field is presented on a large map in Appendix 1. 


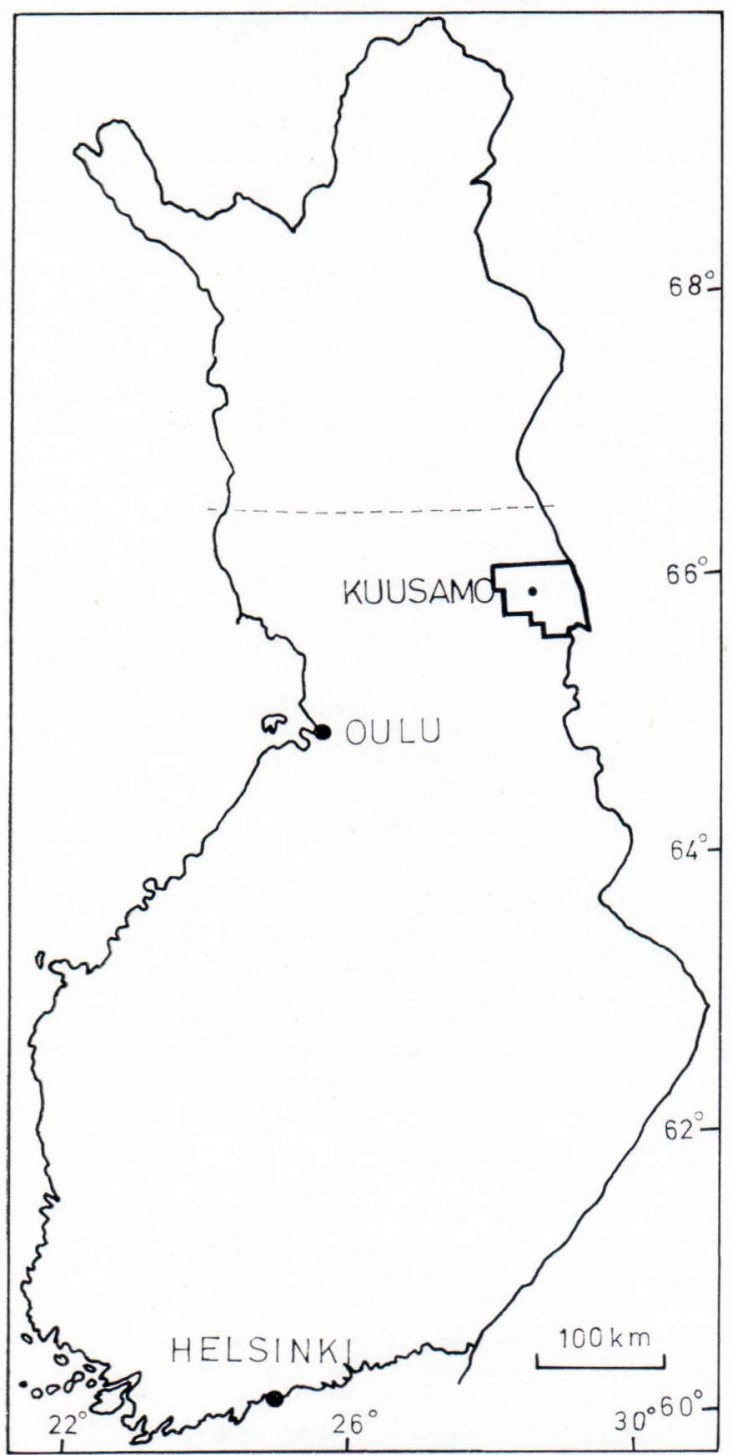

Fig. 1. The Kuusamo drumlin field, in the SE part of northern Finland.

The Kuusamo drumlin field lies on a high upland area, about $230-320 \mathrm{~m}$ above sea level. The highest points, $420-480 \mathrm{~m}$ above sea level, are the summits of the following small mountains called »vaara»: Kuntivaara (480.9), Iivaara (469.4), Pyhätunturi (455), Penikkavaara (435) and Naatikkavaara $(430 \mathrm{~m})$. The relative elevations of the terrain vary from 5 to $200 \mathrm{~m}$, in general from $5-40 \mathrm{~m}$. This upland area is rich in bogs and lakes. The greatest lakes are YliKitka (240.2), Joukamojärvi (252.0), Kuusamojärvi (252.8), Muojärvi (252.8) and Iijärvi (254.0 $\mathrm{m}$ above sea level). The drumlin field is very scarcely inhabited, the village of Kuusamo being the only greater place in the area.

\section{Drumlin types}

The dimensions of the typical drumlins vary in length from 0.2 to $4 \mathrm{~km}$, in width from 50 to $800 \mathrm{~m}$ and in height from 2 to $40 \mathrm{~m}$. These dimensions are thus not so large as the dimensions recorded in central Finland. According to Glückert (1973) the largest typical drumlins in central Finland are $7 \mathrm{~km}$ long, more than $110 \mathrm{~m}$ high and $2 \mathrm{~km}$ wide. The drumlinized vaara hills of Kuusamo are much larger (200 m high) than other drumlins in Finland.

The drumlins in Kuusamo vary in shape and size considerably. The highest point lies in the middle or proximal part of the ridge. Some ridges are quite long and so flat that their highest point cannot be identified.

The drumlins in Kuusamo can be divided into four different types of shape which are presented in Fig. 2. Broad hills of irregular shape, about $20-200 \mathrm{~m}$ high, $0.5-5 \mathrm{~km}$ wide, and $1.5-7 \mathrm{~km}$ long, are called drumlins of the vaara type ( $\mathrm{A}$ in Fig. 2). The largest vaara drumlins, e.g. Kuntivaara (481) and Naatikkavaara (430 m), are 150$200 \mathrm{~m}$ high, the smaller vaara hills instead, mostly $20-60 \mathrm{~m}$ high. The vaara drumlins have a core of bedrock often exposed at the summit of the middle part or proximal end of the ridge. They sometimes resemble a large rock drumlin or a drumlin shield.

The summits of the vaara drumlins lie in general 290-380 m above sea level. Normally there grow plenty of spruce trees on these ridges, whereas the main species on another type, the narrow esker-like drumlin, is pine. There are no drumlins of the vaara type in central Finland, 


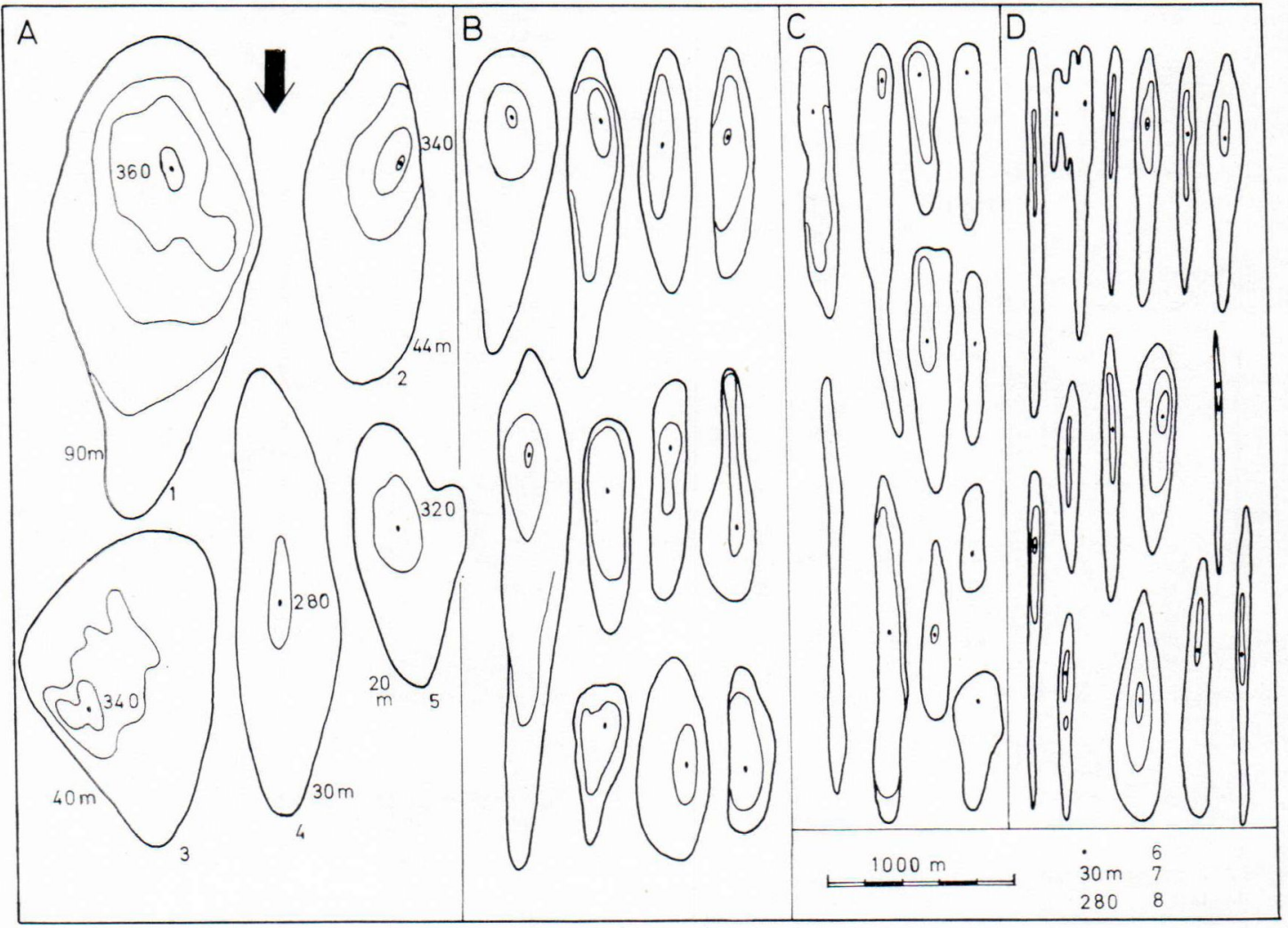

Fig. 2. Drumlin types of the Kuusamo drumlin field. A, high $(20-200 \mathrm{~m})$ irregular drumlins of the vaara type: 1, Akonvaara (Top. map sheet 4523 03), 2, Pieni Siikavaara (4521 12), 3, Lomavaara (4521 12), 4, Piippuaho (4524 09) and 5, Vanhavaara (4521 12); B, typical drumlins ( 8 - $40 \mathrm{~m}$ ), $\mathrm{C}$, low (2-8 m) bog drumlins, D, high $(8-30 \mathrm{~m})$ narrow esker-like drumlins; 6 , highest point(s) of drumlin, 7 , relative height of drumlin, 8, height of summit above sea level. Black arrow $=$ direction of ice advance; the shape of the drumlin is indicated by a few contour lines.

but some high rounded drumlinized hills in the area of Suomenselkä resemble them.

The typical drumlins are mostly oval ridges, 2 $40 \mathrm{~m}$ high, $0.5-3 \mathrm{~km}$ long and $0.1-0.8 \mathrm{~km}$ wide. Spruce trees grow on these ridges, and sometimes even pine. The rock core is seldom exposed, but lies deeper inside of the proximal end or the middle part of the ridge ( $B$ and $C$ in Fig. 2). The typical drumlins are divided into two subtypes: flat low $(2-8 \mathrm{~m})$ bog drumlins, which form very low ridges in bog areas (C). The bigger type (B) is broader and higher (8$35 \mathrm{~m}$ ). The proximal end is often rounded and the middle part of the ridge (B) higher and broader than its distal side (Fig. 3 and 4). A spe- cial drumlin type of the typical drumlins in Kuusamo is the esker-like ridge (D in Fig. 2). These very narrow, sharp-end, symmetrical ridges, 8 $30 \mathrm{~m}$ high, are found in some areas of the drumlin field, especially near the Finnish-Russian border $S$ and SE of Iivaara (Top. maps 4523 08, 10-11 and $454101-02)$. There are normally only pine trees growing on these ridges, and their appearance closely resembles an esker and the sharp-end drumlin type in central Finland (Glückert 1973). The esker-like drumlins have no core inside, or it lies very deep in the central parts of the ridge (Fig. 5).

Tanner (1938 p. 490-492) has described the drumlin topography of Kuusamo in the areas of 


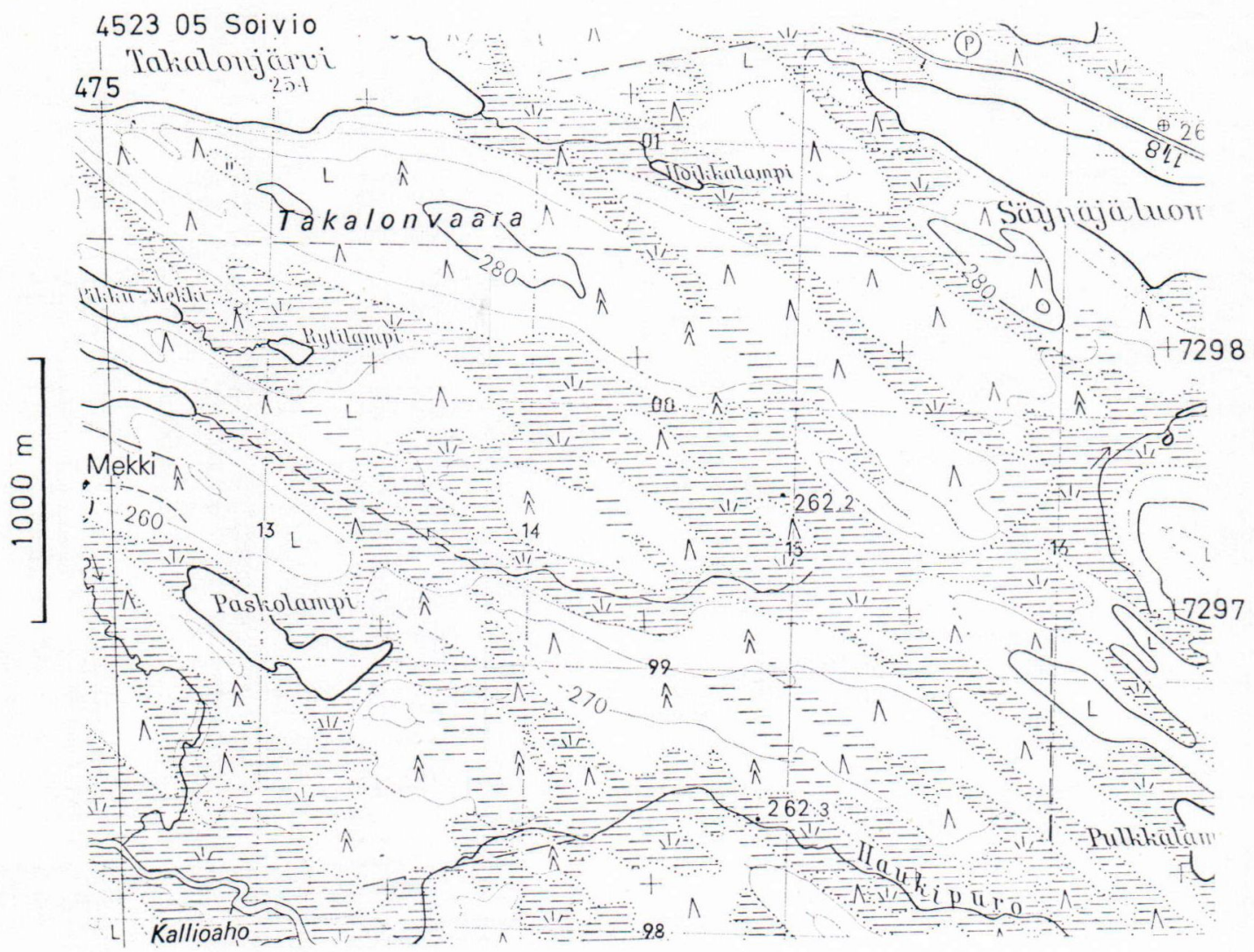

Fig. 3. Low bog drumlins and one vaara drumlin (Takalonvaara) near Soivio. Top. map 452305 Soivio 1968.

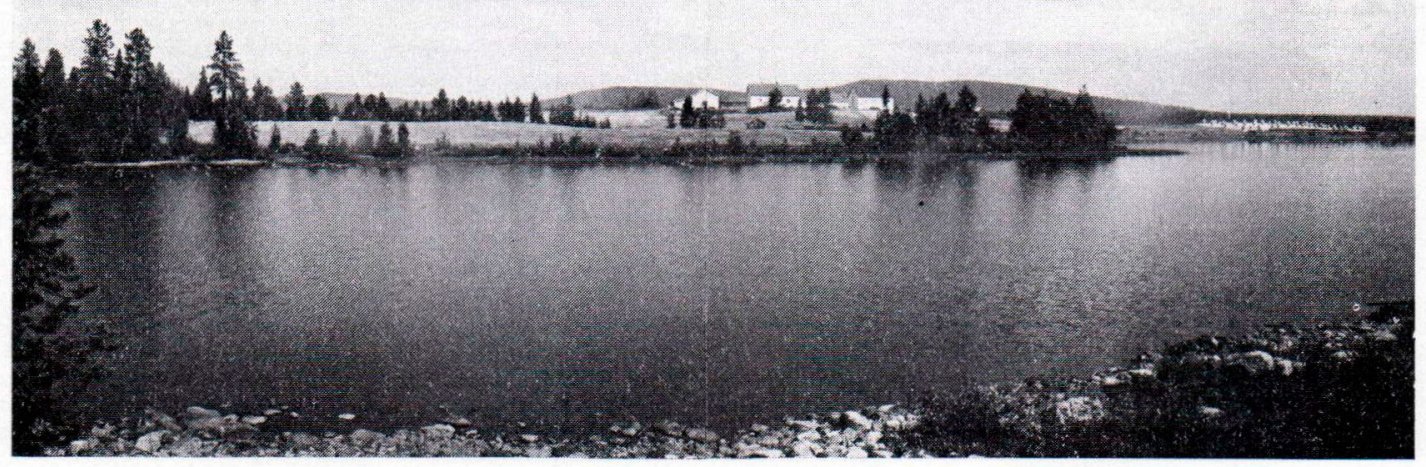

Fig. 4. Typical drumlins forming two long peninsulas at Penikanniemi, lake Penikkajärvi $(256.0 \mathrm{~m}$ above sea level), near Kallioluoma. In the background rise the vaara drumlins of Iivaara (left) and Penikkavaara. Top. map 452308 Pikkarainen 1968.

Photo Glückert 26. 7. 1973. 


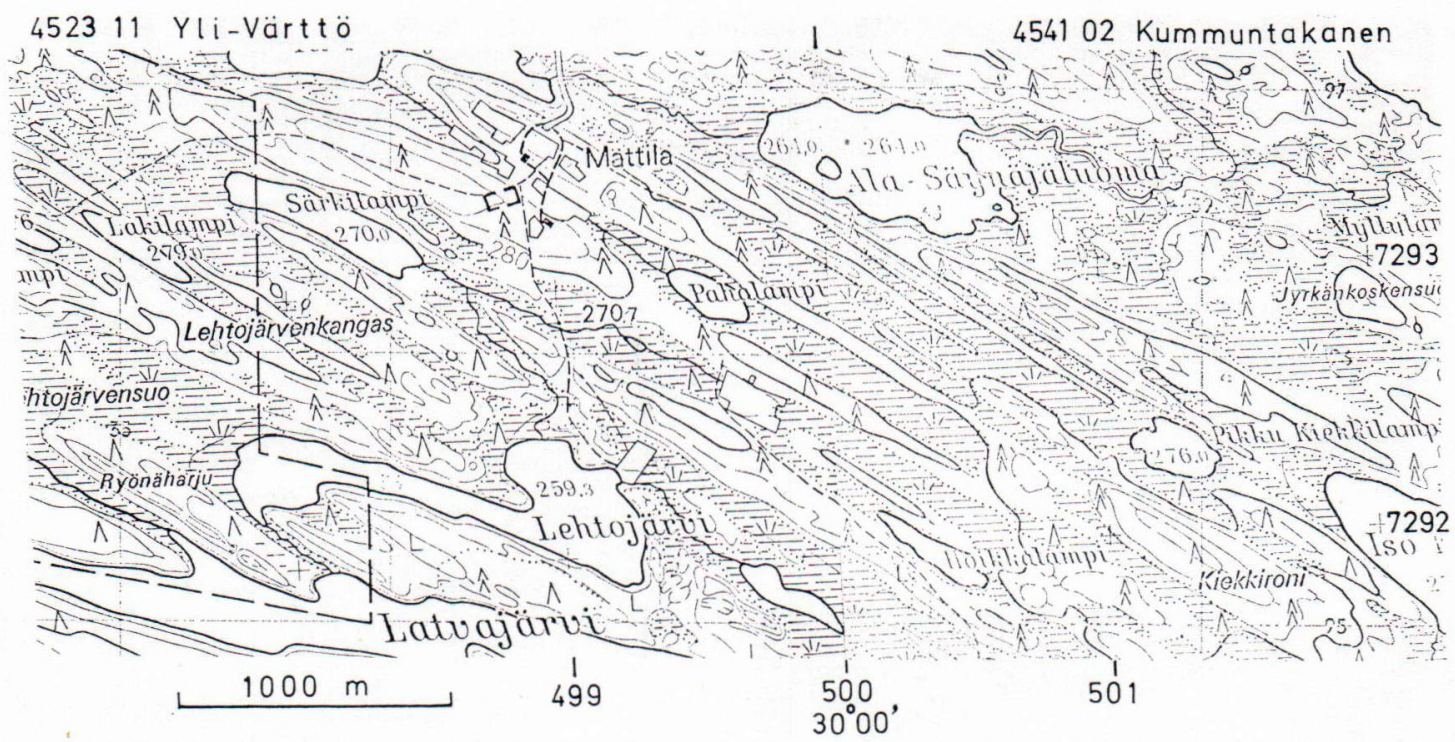

Fig. 5. Narrow esker-like drumlins S of Tammela. Top. maps 452311 Yli-Värttö 1969 and 454102 Kummuntakanen 1969.

Iivaara, Kiitämäjärvi and Vuotunki. Hänninen (1915 p. 12-14) divides the drumlins in Kuusamo into three geomorphological types, welldeveloped ridges, vaara drumlins and mountains or fjelds. The vaara ridges are sometimes rock drumlins, the large ones drumlin shields.

Three discontinuous longitudinal esker systems run across the field in approximately the same direction (ESE) as the drumlins. The $N \ddot{a}$ rängänvaara-Kuparivaara esker is about $40 \mathrm{~km}$ long, runs in the southern part of the field and ends at Kuparivaara. A small ridge belonging to the same system is to be found west of Oijusluoma. Separate prominent esker formations in this system are Kaarronharju and Salmikangas (Appendix 1).

The Parvajärvi-Poussu esker system, including e.g. the Öljynharju and Loukkuharju formations, runs in the SE and middle parts of the field. The Kunrna-Oivanki esker system runs across the whole field, through Muojärvi via Kuusamo and turns to the W in the vicinity of lake Yli-Kitka. The largest separate formations belonging to this system are the eskers of Leveäkangas, Luikonkangas, Välikangas and Telkkäharju (Appen$\operatorname{dix} 1)$.

\section{Composition and genesis}

The drumlins in Kuusamo are composed of grey sandy and silty till, not very rich in stones and blocks. Even in the narrow esker-like ridges the material is till, although they are covered with a thin layer on fine sand. Most of the eskerlike ridges have no core of bedrock inside consisting entirely of basal till. Most of the typical and vaara drumlins, on the other hand, have a distinct core of rock (Fig. 6 and 7).

The drumlins in Kuusamo were produced under moving ice during the period of glacial advance of the continental ice sheet. The esker-like ridges may have got their final shape under the oscillated margin of the ice during deglaciation. These esker-like till drumlins have been formed mainly by deposition. The erosional processes are important for the formation of the final 


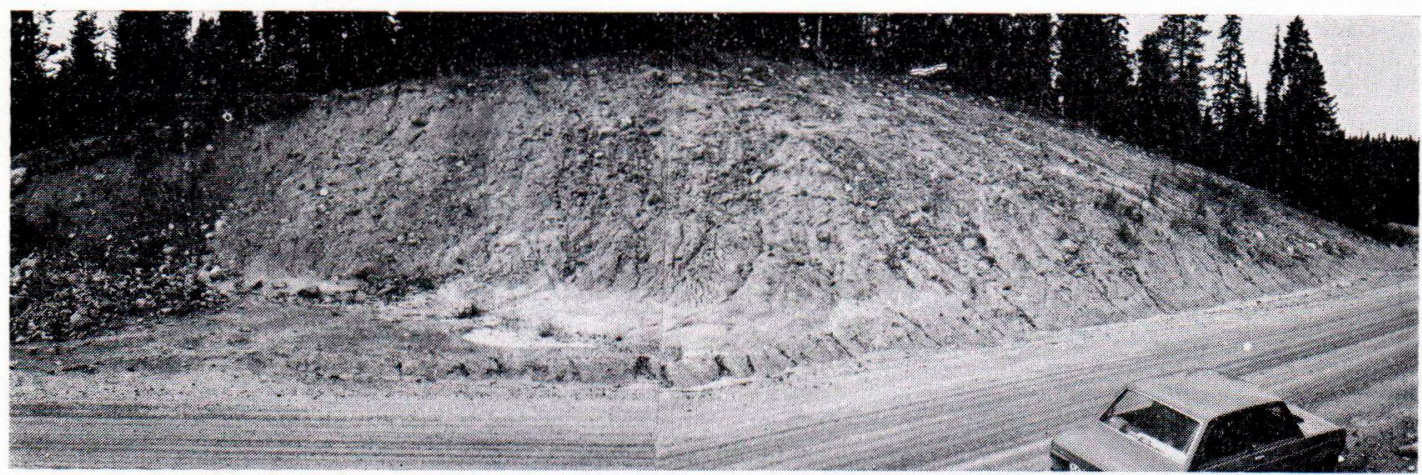

Fig. 6. Road cutting a typical drumlin at Ulkulampi, Tammela. Top. map 454103 Kuurna 1969. Photo Glückert 26. 7. 1973.

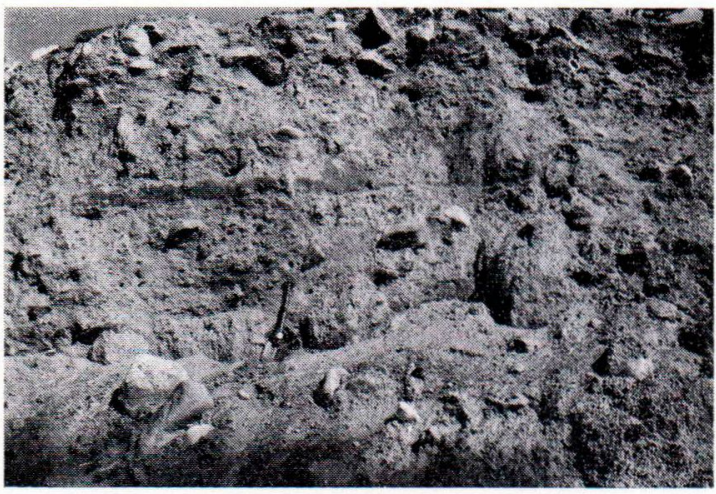

Fig. 7. The drumlins in Kuusamo consist of grey sandy till, not very rich in stones and blocks. The proximal end of a typical drumlin at Soivio. Top. map 452305 Soivio 1968.

Photo Glückert 26. 7. 1973.

streamlined shape of till drumlins. Hill (1971) describes such drumlins in an area in northern Ireland.

Both the orinetation of the ridges and the striae show that the ice moved roughly to the ESE and retreated to the WNW. Observations on striae in Kuusamo indicate that the movement of the ice took place from the WNW-NW $(290$ $\left.-310^{\circ}\right)$. The drumlins show that the ice flowed from the NW $\left(305-310^{\circ}\right)$ in the southern part and from the WNW $\left(290-295^{\circ}\right)$ in the northern part of the drumlin field (Appendix 1).

In general drumlins and striae originated in the period of glacial advance, the eskers, and perhaps the esker-like ridges, during deglaciation.

\section{REFERENCES}

Aartolahti, Toive (1966) Koijärven-Urjalan drumliinikenttä. Summary: The Koijärvi-Urjala drumlin field. Terra 78, pp. 42-50.

Frosterus, Benj. (1913) Suomen geologinen yleiskartta. Lehti C 2, Mikkeli. Maalajikartan selitys. Geologinen toimisto. 49 pp.

Glückert, Gunnar (1973) Two large drumlin fields in central Finland. Fennia 120, 37 pp.

Hinl, A. R., (1971) The internal composition and structure of drumlins in north Down and south Antrim, northern Ireland. - Geografiska Annaler 53, Ser. A, 1, pp. 14-31.

HänNinen, KAARLo (1915) Drumliinimaisemien järvistä ja reiteistä Oulankajoen alueella Kuusamossa. Referat: Über die Seen und Seenketten der Drumlinlandschaften im Gebiet des Flusses Oulankajoki, Kirchspiel Kuusamo (Finnland). Meddelanden av Geografiska Föreningen i Finland. Suomen Maantieteellisen yhdistyksen julkaisuja 9, 1915-1920, 153 pp.

Sauramo, Matri (1928) Jääkaudesta nykyaikaan. 231 pp. Porvoo.

TANner, V. (1938) Die Oberflächengestaltung Finnlands. Bidrag till kännedom af Finlands natur och folk 86, $762 \mathrm{pp}$.

Virkkala, K. (1949) Suomen geologinen yleiskartta. Lehti D 4, Nurmes. Maalajikartan selitys. (The General Geological Map of Finland. Sheet D 4, Nurmes. Explanation to the map of superficial deposits). The Geological Survey of Finland. 54 pp.

- (1961) On the glacial geology of the Hämeenlinna region, southern Finland. Bulletin de la Commission géologique de Finlande 196, pp. 215-242.

Manuscript received, October 5, 1973. 
MAP OF GLACIAL STRIATION

OF THE SCANDINAVIAN ICE SHEET DURING THE LAST (WEICHSEL)

GLACIATION IN NORTHERN EUROPE

Compiled from various sources

by GLÜCKERT 1973

$\searrow$ Glacial striae

Supposed position of the main ice divide during last phase of glaciation
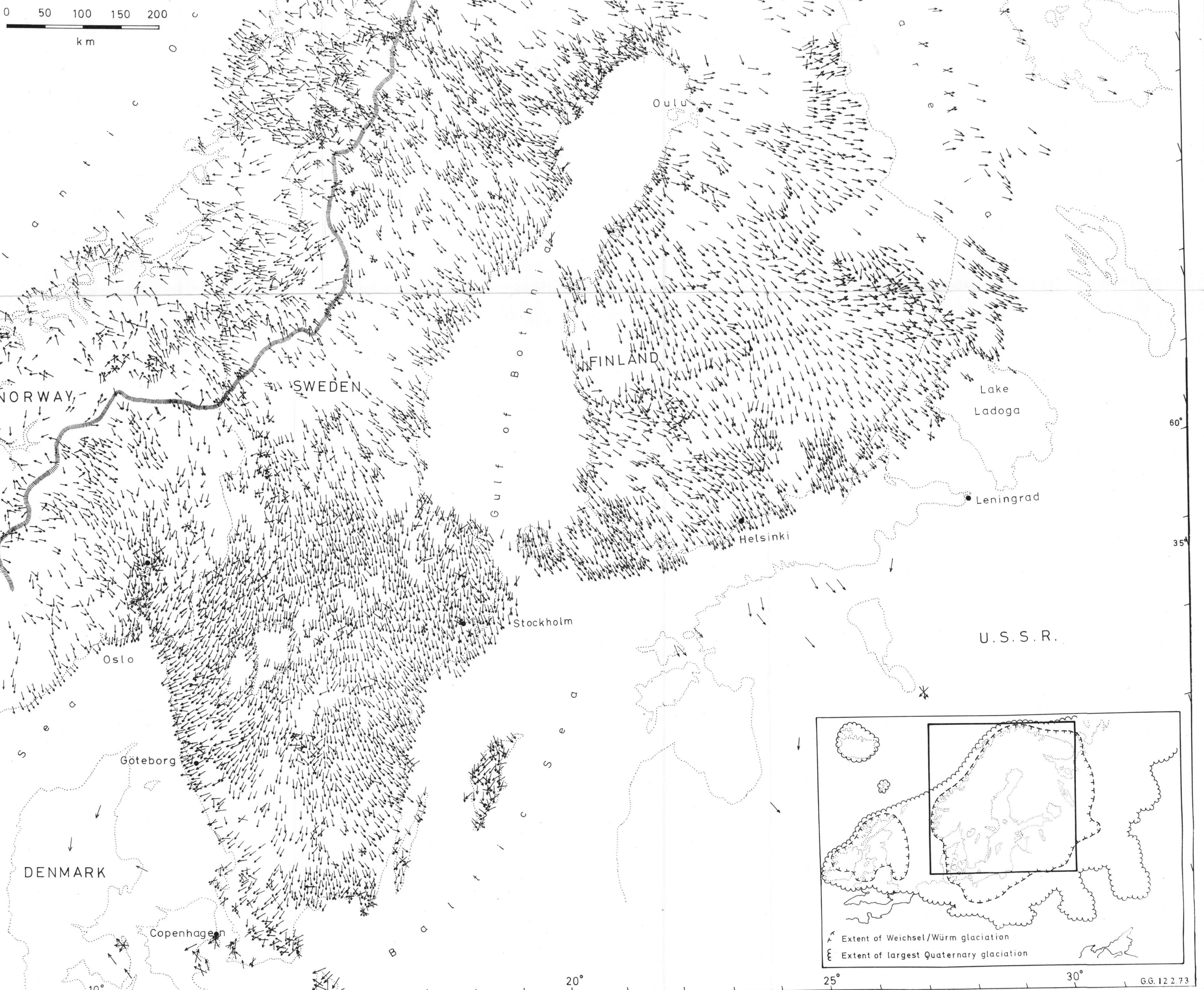


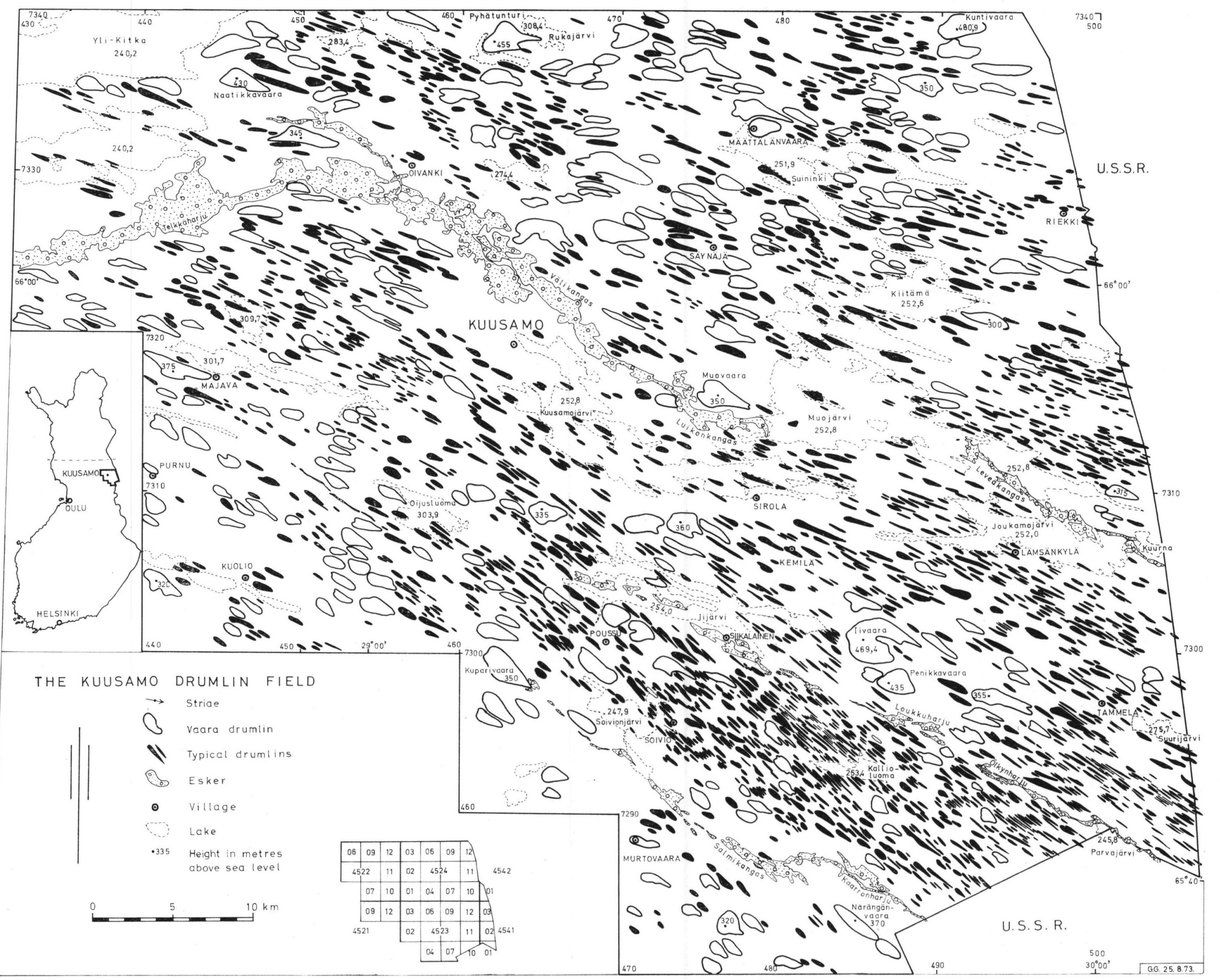


Bull. Geol. Soc. Finland, 43-51 (1974)

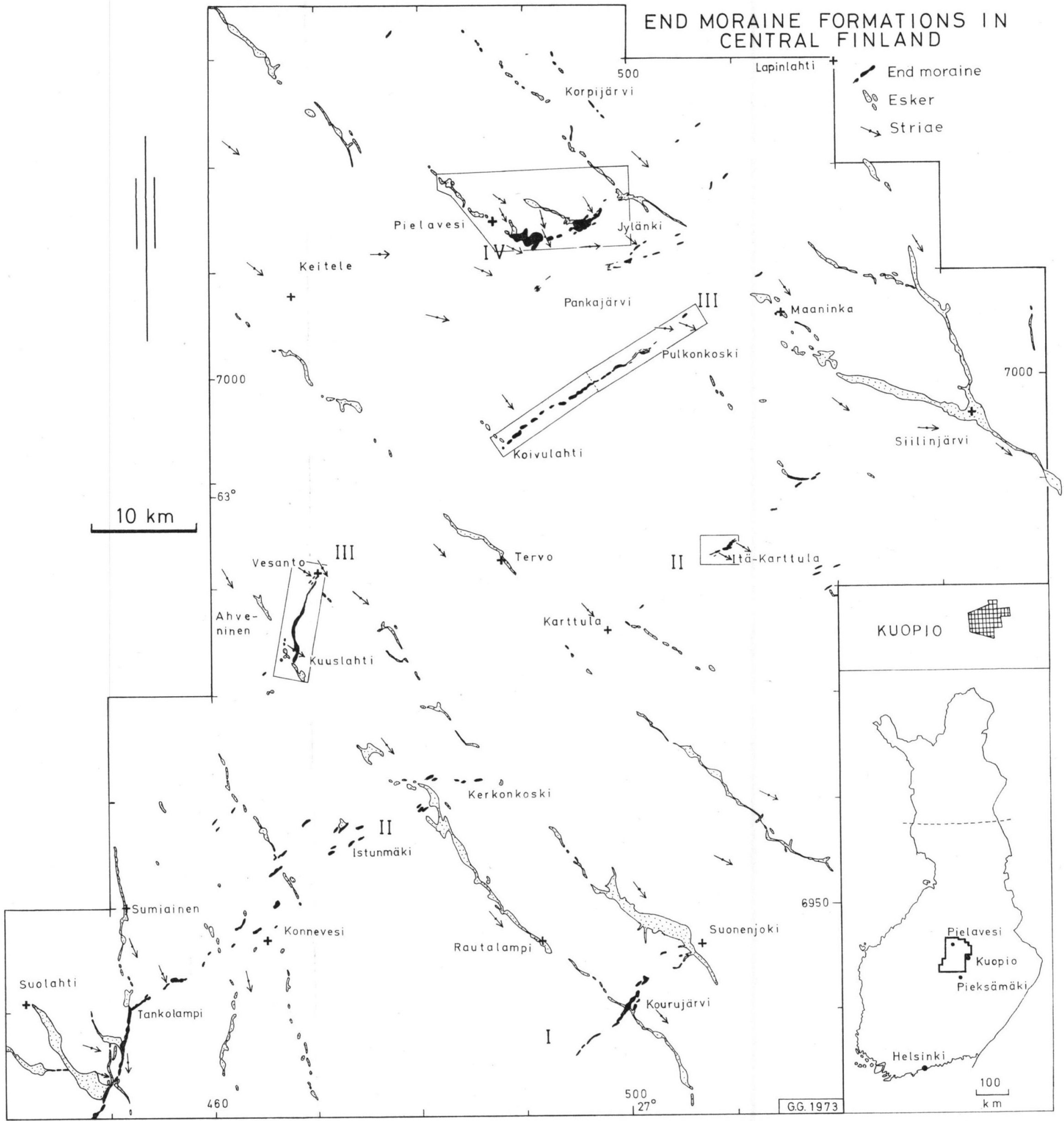

Gunnar Glückert: On deglaciation between Pieksämäki and Pielavesi in central Finland. 